\title{
A COOPERAÇÃO ENQUANTO ELO ENTRE OS SUJEITOS E UMA VISÃO CIVILIZATÓRIA DO PROCESSO
}

\author{
COOPERATION AS A LINK BETWEEN THE SUBJECTS AND A CIVILIZING VISION \\ OF THE PROCESS
}

\begin{abstract}
Vitor Faria Morelato
Mestrando em Direito Processual Civil pelo Programa de Pós-Graduação em Direito Processual (PPGDIR) da Universidade Federal do Espírito Santo - UFES, especialista em Direito Civil e Empresarial pela Faculdade de Direito de Vitória - FDV e especialista em Direito Empresarial pelo LLM da Fundação Getúlio Vargas - FGV, graduado em Direito pela Faculdade de Direito de Vitória. Advogado sócio do escritório Guiotto, Leal \& Pretti Advogados Associados.E-mail:vitormorelato@gmail.com
\end{abstract}

\section{Brunela Vieira de Vincenzi}

Doutora em Filosofia e Filosofia do Direito pela Johann Wolfgang Goethe Universität Frankfurt am Main com Bolsa de Doutorado Integral durante o mesmo período concedida pela CAPES em cooperação com o DAAD (Deutscher Akademischer Austauschdienst). Mestra em Direito Processual pela Universidade de São Paulo. Graduada em Direito pela Universidade Federal do Espírito Santo. Estágio de Pós-Doutorado no Núcleo de Estudos da Violência da Universidade de São Paulo e no Institut für Sozialforschung em Frankfurt am Main, na Alemanha (2009-2010) e pós-Doutoramento no Programa de Pós-Graduação

da Universidade Federal do Espírito Santo - UFES, com bolsa integral PNPD/CAPES (2013-2014), sobre o tema Crise de Confiança nas Instituições Democráticas da Estrutura do Sistema Judiciário no Brasil. Titular da Cátedra Sérgio Vieira de Mello do Alto Comissariado das Nações Unidas para Refugiados na UFES. Atualmente, é Professora do Departamento de Direito da Universidade Federal do Espírito Santo - UFES, onde leciona na graduação e no mestrado, preside a Comissão Interdisciplinar de Apoio aos Refugiados e Migrantes na UFES, Membro da Comissão de Direitos Humanos da UFES e da

Comissão especial com o objetivo de proceder à análise e sugerir melhorias no sistema de segurança da UFES, sendo atualmente também Representante do Centro de Ciências

Jurídicas e Econômicas na Câmara de Extensão da Pró-Reitoria de Extensão - UFES e Sub-Coordenadora do Programa de Licenciatura Intercultural Indígena (PROLIND/UFES 2015). Vice-Presidente da Associação Nacional de Direitos Humanos, Pesquisa e PósGraduação (ANDHEP). E-mail:bruvincenzi@gmail.com

Recebido em: 10/07/2017 Aprovado em: 27/12/2017

RESUMO:Ao se analisar o artigo $6^{\circ}$ do novo Código de Processo Civil, percebe-se um esforço da lei em atribuir um dever de cooperação, destinado aos sujeitos do processo, para o alcance da decisão de mérito. Sobre tal dispositivo, há posição doutrinária que o compreende inconstitucional, porquanto contraditório à própria essência litigiosa do processo, a qual se baseia na noção individualista e naturalista de Thomas Hobbes. Nesse contexto, nos valemos de elementos da filosofia e sociologia contemporânea, como em Habermas, para contestar essa visão da pessoa como ser naturalmente violento, substituindo por um sujeito fruto da interação com os demais membros da sociedade onde está inserido. A partir dessa noção elementar, procuramos demonstrar que a adoção de novos métodos de aplicação da norma depende predominantemente do aplicador, que poderá enxergar no novo CPC um instrumento de fomento ao diálogo, ou 
manter a leitura individualista predominante no texto da lei revogada, de 1973. Para fundamentar a possibilidade de uma nova leitura, dialógica, buscamos na doutrina elementos dogmáticos que corroboram a existência de normas jurídicas, princípios e regras, voltadas para a efetivação da cooperação como instrumento de fomento ao contraditório, contribuindo para ampliar a participação e, consequentemente, a legitimidade do método de solução adotado para cada conflito.

Palavras-chave: Processo civil. Cooperação. Interação. Intersubjetivismo. Contraditório. Teoria da Norma.

ABSTRACT:From the analysis of the article 6 of the new Code of Civil Procedure (CPC), we perceive an effort by the law to assign a duty of cooperation, aimed at the subjects of the process, to reach the decision on merit. On this article, there is a doctrinal position that understands it unconstitutional, as contradictory to the very litigious essence of the process, which is based on the individualistic and naturalistic notion of Thomas Hobbes. In this context, we use elements of contemporary philosophy and sociology, as in Habermas, to challenge this view of the person as a naturally violent being, replacing by a subject the result of interaction with other members of society where it is inserted. From this basic notion, we try to demonstrate that the adoption of new methods of applying the norm depends predominantly on the applicator, who may see in the new CPC as an instrument to promote dialogue, or maintain the predominant individualist reading in the text of the repealed law of 1973. In order to justify the possibility of a new, dialogical reading, we seek in the doctrine dogmatic elements that corroborate the existence of juridical norms, principles and rules, aimed at the accomplishment of cooperation as an instrument of promotion to the contradictory, contributing to increase the participation and consequently, the legitimacy of the method of solution adopted for each conflict.

Key-Word: Civil procedural law. Cooperation.Interaction.Intersubjectivism.Contradictory. Theory of the norm.

SUMÁRIO: 1 Introdução; 2 O processo enquanto marco civilizatório; 3 Os sujeitos do processo para o novo CPC e a desconstrução do centralismo no juiz; 4 A cooperação como princípio, regra e modelo de organização de um processo definido pelo contraditório; 5 A eficácia normativa da cooperação; 5.1 Os deveres dos sujeitos imparciais: esclarecimento; 5.2 Os deveres dos sujeitos imparciais: consulta; 5.3 Os deveres dos sujeitos imparciais: prevenção; 5.4 Os deveres dos sujeitos parciais; Conclusões; Referências.

\section{INTRODUÇÃO}

A promulgação de um novo Código é o marco do nascimento de um novo sistema, o qual será construído a partir de um novo texto aliado à leitura e interpretação do operador do direito. Em notas introdutórias, Fredie Didier Jr. (2015a, p.21) adverte que "é preciso construir, a partir de agora, o sistema do processo civil brasileiro", e que seu "Curso de direito processual civil” está sendo reconstruído, repensado, não apenas atualizado.

Essa necessidade de construção do novo sistema parte da base elementar de que "as normas são formadas pelo intérprete a partir dos dispositivos e do seu significado usual" (ÁVILA, 2004, p.60), de modo que a norma jurídica, enquanto elemento do sistema jurídico, não decorre da mera existência do texto, mas do resultado do exercício interpretativo.

A título de ilustração, foram exatamente as transformações históricas da sociedade - e consequentemente do olhar interpretativo - que deram base à substancial reforma do antigo sistema processual brasileiro quando da promulgação da Constituição em 1988, a qual serviu de 
fonte do núcleo principiológico do Código de Processo Civil (CPC) de 1973, alterando o modo de se trabalhar o processo (MAZZEI, 2014, p. 177-180).

A criação de um novo sistema processual, portanto, perpassa tanto pelos olhares da sociedade que lê e aplica o texto, como pelo texto em si. Isso significa que o novo CPC é o ponto de partida, mas, um novo sistema não nascerá, de fato, caso o aplicador se mantenha preso às antigas amarras conceituais.

Uma dessas notáveis adequações entre texto e destinatário da lei está positivada no artigo $6^{\mathrm{o}}$ do Código, ao dizer que "todos os sujeitos do processo devem cooperar entre si para que se obtenha, em tempo razoável, decisão de mérito justa e efetiva", em dispositivo topograficamente localizado na base do CPC, dedicada às normas fundamentais do processo.

Deve se ter por premissa que o texto legal não limita o alcance da cooperação às partes, mas a todos os "sujeitos do processo", cujo objetivo não é estabelecer uma obrigatoriedade de paz e harmonia entre partes litigantes, mas de busca por uma decisão de mérito justa, efetiva e em tempo razoável.

Como se verá no decorrer do presente trabalho, o CPC não se limitou a trazer, em seu capítulo introdutório, preceitos principiológicos, o que, por si, já seria suficiente para fazer nascer a norma jurídica. Tanto em relação à cooperação como a outros princípios, o Código cuidou também de reiterar esses preceitos em todo diploma processual, mediante regras esparsas que reforçam a leitura conjunta e sistemática entre cada regra e o princípio basilar, bem como definiu a eficácia normativa e os limites dessa cooperação.

Contudo, especificamente no que concerne à cooperação prevista no artigo $6^{\circ}$, parte da doutrina discorda de sua eficácia, ou mesmo de sua constitucionalidade. A título de exemplo, Lênio Streck teceu duras críticas em seu artigo "Cooperação processual no novo CPC é incompatível com a Constituição" ao defender que o legislador depositou "sobre as costas do jurisdicionado parcela imprevisível do peso da responsabilidade que compete ao Estado por determinação constitucional.” (STRECK, 2016, p. 01). E avança:

Então agora as partes deverão cooperar entre si? Parte e contraparte de mãos dadas a fim de alcançarem a pacificação social... Sem ironias, mas parece que Hobbes foi expungido da "natureza humana". Freud também. O novo CPC aposta em Rousseau. No homem bom. Ou seja, com um canetaço, num passe de mágica, desaparece o hiato que as separa justamente em razão do litígio. Nem é preciso dizer que o legislador pecou ao tentar desnudar a cooperação aventurando-se em setor cuja atuação merece ficar a cargo exclusivo da doutrina. E o fez mal porque referido texto legislativo está desacoplado da realidade, onde as partes ali se encontram sobretudo para lograr êxito em suas pretensões. Isso é, digamos assim, natural, pois não? Disputar coisas é uma coisa normal. Não fosse assim não haveria "direito". Direito é interdição. É opção entre civilização e barbárie. Desculpem-nos nossa franqueza. (STRECK, 2016, p. 02).

Para o autor, as partes e advogados possuem o direito de adotarem as medidas cabíveis para que o processo chegue a um fim parcial, ou seja, eles não têm qualquer dever de alcance à verdade real, ou, nas palavras dele, a "verdade superior". A cooperação, nessa linha de raciocínio, privaria a liberdade das partes e advogados, os quais seriam transformados em ferramentas do juiz na busca da "justiça”, atribuindo-lhes um "espírito filantrópico" que, em verdade, não existe.

Para citar outro exemplo, Daniel Amorim Neves parece concordar com Lênio Streck, ao advertir que o artigo $6^{\circ}$ correrá o risco de se transformar em letra morta, porquanto utópico, caso seja interpretado no sentido de obrigarem as partes a colaborarem, de forma solidária, entre si. Para os autores, o dispositivo deveria ser lido dando enfoque apenas na relação entre o juiz e cada parte em prol do julgamento de mérito (NEVES, 2015, p. 16-19), ou seja, o dever de cooperação 
seria direcionado ao juiz, o qual deveria cooperar com as partes para que ele, na condição de único julgador, alcançasse o mérito.

Como será tratado no decorrer do presente trabalho, parte da doutrina diverge do entendimento exposto acima ${ }^{1}$, atraindo-se o risco de o nascente princípio não ser aplicado em sua integralidade. Entendemos que o artigo $6^{\circ}$ apresenta um princípio que vai ao encontro das regras e limites da ponderação, o que afasta o risco de se pretender que as partes passem a andar de mãos dadas em prol de uma verdade real impossível de se alcançar.

Neste sentido, como já dito, o próprio código tratou de apresentar regras, em consonância com a cooperação, no sentido de apresentar sua eficácia normativa e seus limites. Isso pode significar, por exemplo, que o termo "todos os sujeitos do processo", do artigo $6^{\circ}$, tenha amplitude superior à apenas partes, advogados e juiz; e ainda, que o termo "decisão de mérito justa e efetiva" não se confunde com verdade real, ou "verdade superior".

Para fins de parametrização terminológica, compreende-se, no presente texto, que o termo "decisão de mérito justa e efetiva", trazido pelo artigo $6^{\circ}$ carrega o sentido exposto por Hermes Zaneti (2005, p. 124):

A verdade absoluta no processo civil não pode ser jamais atingida. $O$ que se obtém é, no máximo, um juízo de probabilidade, uma verdade provável. Este juízo de verossimilhança, que aporta ao final do processo com alto grau de probabilidade de ser verdadeiro, é alçado à 'certeza' (sic.) com o trânsito em julgado da decisão, erigindo-se em um patamar de 'certeza jurídica' (rectius: estabilidade e previsibilidade). Com efeito, a doutrina é uníssona ao apontar que '...como a certeza absoluta é sempre inatingível, precisa o operador do sistema conformar-se com a probabilidade, cabendo-lhe a criteriosa avaliação da probabilidade suficiente.

[negritos e itálicos presentes no original do texto]

Neste contexto, rememoramos que há mais um elemento fundamental para a compreensão desse novo sistema processual, que vai além da análise interpretativa do texto legal: trata-se da sociedade para a qual o texto é dirigido, a qual formará a norma enquanto intérprete da lei.

Diante disso, objetivamos, pelo presente estudo, colocar a cooperação em discussão, mediante sua análise como um princípio integrante e integrador de uma nova ordem jurídica processual, bem como por meio do levantamento de instrumentos legais que lhe conferem eficácia.

Procuraremos, ainda, relacionar a cooperação aos sujeitos do processo, problematizando quem seriam esses sujeitos indicados como destinatários do texto do artigo $6^{\circ}$. Não é nossa pretensão tecer detalhes sobre cada sujeito do processo individualmente, para não perdermos o foco. Analisaremos, de forma geral, quem são esses "sujeitos", bem como sua participação na decisão de "mérito justa e efetiva", e, assim, contribuir para a instigação do debate acadêmico sobre o novo sistema processual.

\section{O PROCESSO ENQUANTO MARCO CIVILIZATÓRIO}

O ponto de partida nesse tópico são as críticas trazidas na introdução do presente trabalho, de modo que, diversamente ao que defende Streck, argumentamos que o legislador, ao elevar as possibilidades de cooperação do jurisdicionado, não delegou (desviou) indevidamente o poder/dever Estatal, ou mesmo atribuiu deveres que não caberia ao jurisdicionado. Entendemos

\footnotetext{
${ }^{1}$ Como se verá dos capítulos seguintes, a título de exemplo: Barreiros (2011), Didier Jr. (2010, 2015a e 2015b),
} Mitidiero (2007), dentre outros. 
que a cooperação institucionaliza a participação do indivíduo nas práticas sociais formalmente estabelecidas - aqui, especificamente, o processo - afastando a ideia de que o Estado provê soluções aos sujeitos sempre passivos a espera do órgão superior.

A cooperação aproxima o sujeito dos meios de solução dos litígios, os quais, invariavelmente, existem na sociedade. Logo, não se trata de aproximar o processo do conceito de "homem bom" de Rousseau, uma vez que a mera existência do processo reconhece a natureza litigiosa da pessoa.

Contudo, reconhecer a natureza conflituosa da pessoa não significa defender que, ainda hoje, a essência hobbesiana - do homem enquanto lobo do próprio homem -seja um pressuposto validamente aplicado à sociedade brasileira moderna. No contexto social atual, se o intérprete da norma enxergar o Código partindo - mesmo que inconscientemente - do pressuposto teórico de Hobbes, correrá o risco de não compreender a forma como esse texto legal idealmente se relaciona com a pessoa e o ente social.

Isso porque, ao se partir das premissas hobbesianas, percebe-se o humano como ser naturalmente violento, mesmo que racional. Nesse sentido, segundo Renato Janine Ribeiro (2000, p. 55), para Hobbes:

Todo homem é opaco aos olhos de seu semelhante - eu não sei o que o outro deseja, e por isso tenho que fazer uma suposição de qual será a sua atitude mais prudente, mais razoável. Como ele também não sabe o que quero, também é forçado a supor o que farei. Dessas suposições recíprocas, decorre que geralmente o mais razoável para cada um é atacar o outro, ou para vencê-lo, ou simplesmente para evitar um ataque possivel: assim a guerra se generaliza entre os homens. Por isso, se não há um Estado controlando e reprimindo, fazer a guerra contra os outros é a atitude mais racional que eu posso adotar (é preciso enfatizar esse ponto, para ninguém pensar que o 'homem lobo do homem', em guerra contra todos, é um anormal; suas ações e cálculos são os únicos racionais, no estado de natureza).

No entanto, o conceito de violência enquanto premissa racional vai de encontro à noção elementar de interação. Para Hobbes, a pessoa enxergava na violência a saída mais racional a partir da dedução de que o outro agiria da mesma forma. Contudo, o fato de o indivíduo ser um ente social, baseado em interações intersubjetivas, afasta a ideia da violência como medida prévia mais racional, como se verá a seguir.

Dos vários autores modernos que se dedicaram a estudar a natureza dos atos humanos, sempre são destacados aqueles que renderam os maiores debates e, por isso, moldaram o pensamento doutrinário em diversas ciências da modernidade, dentre as quais o Direito (ZIZEK, 2013).

Hobbes, como visto, defendia que os impulsos que movem o homem ao litígio têm origem na busca por autopreservação; Maquiavel, por sua vez, entendia que a lide se originava na busca por poder; Hegel, ao seu turno, enxergava que a fonte da luta constante se dava como reação às ações de desrespeito, naquilo que ele chamou de luta por reconhecimento (CRISSIUMA, 2013, p.28).

Nesse contexto teórico, filósofos pós-metafísicos como Jürgen Habermas e seu sucessor ideológico direto, Axel Honneth, tentam aproximar os conceitos metafísicos dos teóricos modernos - no caso destes, a base predominante é Hegel - aos conceitos pós-metafísicos de ciência. Nota-se que há um notório esforço de relacionar essa base teórica metafísica hegeliana à antropologia, à história e à psicologia em suas diversas abordagens como a psicanálise, a psicologia social e infantil, por exemplo (CRISSIUMA, 2013, p.66-75). 
Habermas, ao desenvolver sua teoria do agir comunicativo, usa extensa base teórica multidisciplinar, com destaque para a psicologia ${ }^{2}$, para concluir que a comunicação é elemento de construção da própria personalidade do indivíduo, de modo que as sociedades se formam e se estabilizam baseadas na medida da solidariedade desses indivíduos. Nesse contexto, os conflitos não seriam a regra, mas anomias que perturbam essa integração (HABERMAS, 1987, p. 200).

A premissa do destinatário da norma como ser baseado na interação, e não na violência, é percebida na base principiológica do Código tratada do artigo $1^{\circ}$ ao 12 , demonstrando, portanto, um afastamento do texto à base teórica hobbesiana. Logo, consequentemente, o intérprete da norma deve ler o texto partindo dessa mesma premissa.

No mesmo sentido, os próprios termos hegelianos de "indivíduo" e "sujeito" como acepções distintas, aliadas aos conceitos científicos atuais, pode influenciar a leitura do CPC ao se valer de termos como "sujeitos do processo".

Com isso não estamos defendendo aqui, que o legislador brasileiro necessariamente, e intencionalmente, partiu de Hegel para criar o termo positivado "sujeitos do processo" (em verdade, não encontramos estudos que confirmem ou afastem essa hipótese). Contudo, a identidade de termos pode dar luz ao intérprete (quando da criação da norma a partir da leitura do texto) de, se valendo dos conceitos hegelianos, ver o "sujeito" como uma evolução social do "indivíduo".

Para Hegel, o "indivíduo" é aquele que obtém respeito no interior de sua família por meio da comunhão de valores éticos mutuamente respeitados. O "sujeito", por sua vez, é o "indivíduo" que consegue se fazer respeitado perante a sociedade e o Estado (HONNETH, 2009, p. 60) por meio da participação ativa nos grupos e práticas sociais formais e informais voltadas à efetivação dos direitos (HONNETH, 2015, p. 81).

Essas práticas e grupos sociais decorrem, portanto, do agir comunicativo defendido por Habermas (HONNETH, 2015, p. 81), o que atrai a ideia de que o ser humano é naturalmente social, ou seja, é completamente dependente de relações intersubjetivas.

Ao trazer um rol de "sujeitos do processo", , a norma - enquanto texto interpretado deverá enfatizar tanto as pessoas quanto as relações, tornando o processo um ambiente de trabalho, não um campo de batalha repleto de indivíduos agindo independentemente um do outro. E pensar em um ambiente de trabalho significa compreender o sentido da cooperação tal como exposto pelo Código.

A cooperação - assim como a primazia pela autocomposição e pelo autorregramento da vontade - almeja o aumento das potencialidades sociais e da maturidade do jurisdicionado em prol da solução do processo. A título de ilustração, na sociologia, Roberto Kant de Lima defendeu, em obra publicada em 1999, que o sistema legal norte-americano era fruto de sociedade mais crítica sob o ponto de vista educacional-religioso, uma vez que a origem protestante tradicionalmente voltava mais os olhos à contestação e à leitura interpretativa (LIMA, 1999, p. 26).

Esse é um dos motivos que explicam porque o sistema norte americano é mais negocial, menos impositivo, em comparação ao Brasil (de 1999, quando da publicação do artigo), já que, nos EUA, há regras de barganhas em vários sentidos, mesmo nos processos criminais. Nesse contexto de negociações, o autor conclui que, mesmo "apesar das diversas críticas que este sistema sofre", especialmente por ser mais injusto com as partes mais fracas, "sua lógica é uma, inequívoca e universalmente disponível: a verdade pública é fruto de uma negociação explícita e sistemática entre as partes interessadas"(LIMA, 1999, p. 26-29).

\footnotetext{
${ }^{2} \mathrm{Na}$ psicologia, por exemplo, Freud, Piaget, Mead e Wygotski.Em outras áreas citamos, por exemplo, Weber, Durkheim e Parsons (GUTIERREZ \& ALMEIDA, 2013, p. 159-160).

${ }^{3}$ Deve ser destacado que o rol de "sujeitos do processo" não se limita a autor e réu, cuja relação ruidosa é permeada pelo litígio a ser resolvido. A existência de uma lide, de um ruído à regra da estabilidade e ordem social entre duas partes não pode ser o fio condutor de todas as relações subjetivas, inclusive profissionais, aplicadas sobre o processo.
}

Revista de Direito Brasileira | São Paulo, SP | v. 20 | n. 8 | p. 192-214 |Mai./Ago. 2018 
No Brasil do antigo sistema processual há uma mítica de se buscar a "verdade", a ponto de obrigar a parte a alegar literalmente tudo que quiser em sua defesa, mesmo que caia em contradição - é a consequência elementar do princípio da eventualidade - causando verdadeiros emaranhados de teses e documentos(LIMA, 1999, p. 29).

Daí se extrai que, segundo o antigo sistema, inaugurados pelos Códigos anteriores ao de 2015, o formalismo e a lógica liberal predominavam, dificultando a solução de mérito e contribuindo para o que Kant de Lima destacou como verdadeiros emaranhados de teses e documentos. O antigo sistema decorria de um código, segundo Rodrigo Mazzei (2014, p. 177203) "arraigado dos princípios do liberalismo, preso a uma concepção pouco social", no qual o formalismo era "colocado com farol de iluminação".

E tal característica, evidentemente, não era exclusiva do antigo CPC, já que o mesmo autor também destacou o caráter individualista liberal do Código Civil de 1916, criado para se manter relações patrimonialistas hierarquicamente rígidas da sociedade da época, manter a elite coronelista no poder e o proletariado rural submisso (MAZZEI, 2011, p. 256-257).

Bonavides e Andrade (1991, p. 05), ao seu turno, asseveram, em sua "História constitucional do Brasil", que tal história tem "fundamento elitista porque o povo não a escreveu." E ainda, "o poder soberano do povo, em estado puro, ditando a vontade suprema da Nação, só tem aparecido em ocasiões raras" uma vez que o "exercício político imediato fica frequentemente coartado pela intermediação e infidelidade de governantes habituados ao poder sem freio e sem limitações".

É possível compreender, então, que o antigo sistema legal brasileiro, marcado pelo individualismo e formalismo, afastava o órgão jurisdicional das partes, enquanto no sistema norte-americano, ao contrário, determina-se a condução do processo a partir da vontade das partes, em método liberal também sujeito a críticas. A cooperação seria o método intermediário entre esses dois sistemas e, nas palavras de Didier Jr. (2015b, p. 18) "parece ser o mais adequado para uma democracia".

O que se propõe, portanto, é que a cooperação, assim como outros princípios positivados na introdução do código, apresenta um conjunto de regras e princípios que enxerga uma evolução social do intérprete, e do jurisdicionado, em comparação aos diplomas anteriores, o que, por consequência, alterará a forma como o intérprete enxergará o Código, a partir de uma base teórica em que o processo, mais que um substituto à violência física, é um ambiente de diálogos e instrumento de efetivação de direitos.

\section{OS SUJEITOS DO PROCESSO PARA O NOVO CPC E A DESCONSTRUÇÃO DO CENTRALISMO NO JUIZ}

Como tratado até o presente momento os destinatários da redação do artigo $6^{\circ}$ são os "sujeitos do processo", cuja acepção social e filosófica foi vista no capítulo 2 do presente trabalho. Em consonância com tal sentido, a partir da análise sistemática do texto legal, é possível fazer análise crítica do rol de sujeitos positivados, com a finalidade de se identificar quem, de fato, é o destinatário do dever de cooperação, bem como identificar uma nova forma do CPC inter-relacionar esses sujeitos.

Como já dito, não é nossa pretensão tratar especificamente de cada sujeito, ou mesmo dos direitos e deveres específicos de cada um. Seguramente há premente necessidade do debate dogmático acerca dos direitos e deveres específicos, mas, caso o fizéssemos nesse ambiente, desviaríamos o foco do trabalho.

Seguindo essa linha metodológica, ao analisarmos o contexto histórico do antigo sistema processual, a obra de Antônio Carlos de Araújo Cintra, Ada Pelegrini e Cândido Dinamarco apresentou capítulo introdutório geral acerca dos sujeitos do processo antes de tratar de cada sujeito individualmente. Nesse tópico, os autores falaram de, pelo menos, três sujeitos: "o autor e 
o réu, nos polos contrastantes da relação processual, como sujeitos parciais; e, como sujeito imparcial, o juiz representando o interesse coletivo orientado para a justa resolução do litígio" (CINTRA; GRINOVER; DINAMARCO, 1985, p. 263). No decorrer da obra os autores acrescentam os litisconsortes como sujeitos parciais, o terceiro interveniente como parte, além do advogado e do Ministério Público (CINTRA; GRINOVER; DINAMARCO, 1985, p. 264-269).

Esse esforço doutrinário decorria do fato de o CPC/73 não trazer sistematicamente um rol de sujeitos do processo, cabendo apenas à doutrina o esforço teórico da classificação e sistematização. Naquele Código o Título dedicado às partes e procuradores, por exemplo, estava topograficamente localizado no Livro I (Do processo de conhecimento), no qual o Título II trazia partes, procuradores, litisconsortes, assistentes e intervenientes terceiros; o Título III trazia o Ministério Público. Juiz e auxiliares da justiça estavam, respectivamente, nos Capítulos IV e V do Título IV, depois dos capítulos destinados à competência. No rol de auxiliares da justiça apareciam: o serventuário, o oficial de justiça, o perito, o depositário, o administrador e o intérprete.

Como se vê da doutrina acima citada, os serventuários da justiça, ou o perito - figura essencial na solução do mérito - por exemplo, não foram apropriadamente incluídos na classe "sujeitos do processo", cujo conceito doutrinário valorizava as partes (e aqueles que atuariam como tal), juízes, advogados e Ministério Público.

Com o desenvolvimento do pensamento doutrinário o conceito sofreu alterações. Como se vê em obra de Dinamarco (2003, p.198) o rol foi ampliado, e ainda se manteve a separação entre classes de sujeitos: parciais - partes e advogados - e os imparciais, esses "na qualidade de terceiros alheios ao conflito de interesses" onde estão incluídos juízes e os serventuários da justiça, os quais "mediante atividades complementares lhe dão o apoio indispensável para que a jurisdição possa ser exercida".

Ponto de destaque nessa classificação é a atribuição, dada pelo doutrinador, a diferentes graus de importância atribuídos a cada sujeito, conforme o critério de classificação utilizado: “O juiz e as partes dizem-se sujeitos principais, porque são estas as pessoas envolvidas nos conflitos de interesses trazidos à Justiça e é aquele quem decide a respeito do conflito e dirige o processo." Os sujeitos secundários, por sua vez, seriam "o advogado, que representa as partes, e os auxiliares da Justiça, subordinados ao juiz" (DINAMARCO, 2003, p.198).

A partir de tal classificação, observa-se um critério que atribui notória importância ao "conflito de interesses". Aqueles que, segundo a doutrina, mais se aproxima do "conflito" é classificado como principal, enquanto os que orbitam em esferas mais distantes são considerados secundários.

Nessa ótica, o agir conflituoso das partes - o litígio em si - seria o núcleo do sistema, o qual atrai os demais elementos envolvidos no processo. As peças principais seriam aquelas mais próximas desse núcleo gravitacional: as partes por terem-na criado, e o juiz por ser o único responsável por solucioná-lo. Sedimenta-se, assim, um mecanismo pelo qual um único ente, o Estado-Juiz, é capaz de conduzir os sujeitos à solução, a qual se dará através da atribuição maniqueísta do certo ou errado, de quem tem ou não razão.

No entanto, é possível observar que o novo CPC, em consonância com os ditames constitucionais, alterou essa visão, de modo que a origem do processo (o conflito de interesses), não se confunde com seu objeto, qual seja, a solução conjunta do litígio. Como visto em Habermas, no capítulo anterior, se os conflitos são anomias que perturbam a integração social cuja base é a interação - a mais adequada forma de solução de tal anomia requer uma agir coletivo pela resolução dessa perturbação. E esse agir coletivo não depende exclusivamente do juiz.

Reiteramos que, para que isso seja efetivado, é preciso que a norma seja construída de acordo com essa ótica pelo intérprete, afastando-se da figura do juiz a exclusividade pela solução do conflito. Pela noção atual de cooperação, uma visão centrada no conflito em si (e não nas 
opções de pacificação) e hierarquizada dos sujeitos do processo, com destaque evidente no juiz, afasta a noção de ambiente de trabalho com divisões de atribuições e alternativas de solução.

Isso se destaca na medida em que o juiz não possui a formação necessária para definir plenamente as soluções, como destacado por Dierle Nunes e Alexandre Bahia (2010, p. 89):

Não há como se acreditar que todos os juízes possuam uma formação acadêmica plena (jurídica, administrativa, política, econômica, filosófica e sociológica) que viabilizaria a aplicação do direito (e administração das tramitações procedimentais) sem o subsídio técnico do processo e dos demais sujeitos de direito interessados e participantes (partes, advogados, órgãos do MP, auxiliares do juízo) além de uma logística uniforme de administração das rotinas estruturais.

A construção de um sistema processual centralizado no juiz valoriza situação pouco eficiente ao atribuir a este profissional do direito o dever-poder exclusivo de decidir, por exemplo, questões de fato cuja complexidade técnica exija conhecimento específico para o qual o magistrado não se graduou. Nesses casos, perdem-se tempo e recursos financeiros na contratação de um perito, cuja atribuição pragmática é desvendar ao juiz os ensinamentos de seu ramo de conhecimento. Após o laudo pericial o expert se afasta da atividade - como se seu trabalho estivesse cumprido - cabendo ao juiz, isoladamente, desprender mais tempo e recursos públicos para compreender aquela ciência, para aquele processo, e isoladamente decidir.

$\mathrm{O}$ novo CPC, então, trouxe um conjunto de regras que não são, apropriadamente, novidades no sistema; mas a existência de uma previsão positivada no Código permite uma leitura sistemática mais lógica, voltada para a existência de diversas formas de solução do conflito (que não apenas o certo e errado da sentença), e para a atribuição de funções ao grupo de trabalho que orbita o processo.

Topograficamente, o novo CPC dedicou um livro próprio (o III) aos sujeitos do processo, organizando-os em um rol específico, ou seja, se, no CPC 73, cabia apenas à doutrina classificar os sujeitos do processo, agora o próprio texto legal trouxe o rol (aberto) de sujeitos, o qual, por sua vez, apresenta diferenças em relação ao do antigo. ${ }^{4}$

Essa melhor organização aliada a uma leitura sistemática dos deveres processuais atribuídos aos diversos sujeitos, permite compreender a inclinação legislativa em possibilitar que o processo seja o referido ambiente de trabalho, descentralizando funções e atribuindo responsabilidades.

E o texto legal reforça essa ideia em diversos pontos. A título de exemplo, do artigo 165 ao 175 o CPC não apenas sistematiza conciliadores e mediadores judiciais, como também os centros de solução consensual de conflitos, os quais podem ser públicos ou privados ${ }^{5}$. Em paralelo, posteriormente ao novo Código foi promulgada a Lei 13.140/2015, que dispõe sobre a mediação entre particulares e autocomposição no âmbito da administração pública, reforçando a ideia de descentralização do Estado-Juiz como provedor das soluções.

\footnotetext{
${ }^{4}$ A título de esclarecimento, o novo CPC inova em relação ao seu antecessor ao trazer o amicus curiae, a advocacia pública e a defensoria pública. O artigo 149 aumenta o rol de serventuários da justiça, acrescentando o chefe de secretaria, o tradutor, o mediador, o conciliador judicial, o partidor, o contabilista e o regulador de avarias. A lista é, evidentemente, aberta, uma vez que o próprio artigo 149 determina que também se enquadram no rol de serventuários outros profissionais "cujas atribuições sejam determinadas pelas normas de organização judiciária." Outra demonstração de que o rol permanece aberto é a definição de atribuições a outros sujeitos esparsamente pelo Código, como é o caso, por exemplo, do assistente técnico (artigos 465, $\S 1^{\circ}, \mathrm{II}, 475,477, \S 1^{\circ}$ dentre outros) e do leiloeiro público (artigo 884).

${ }^{5}$ Art. 167. Os conciliadores, os mediadores e as câmaras privadas de conciliação e mediação serão inscritos em cadastro nacional e em cadastro de tribunal de justiça ou de tribunal regional federal, que manterá registro de profissionais habilitados, com indicação de sua área profissional.
}

Revista de Direito Brasileira | São Paulo, SP | v. 20 | n. 8 | p. 192-214 |Mai./Ago. 2018 
A atuação da mediação poderá ocorrer em paralelo ao processo, inclusive podendo suspender sua marcha, conforme artigo $16^{6}$ da Lei 13.140/2015. Inclusive, uma leitura sistemática do Código nos permite concluir que o texto legal não vê no juiz a figura mais recomendada para se conduzir um processo de mediação.

$\mathrm{O}$ artigo 139, ao definir deveres do juiz, expõe no inciso $\mathrm{V}$ "promover, a qualquer tempo, a autocomposição, preferencialmente com auxílio de conciliadores e mediadores judiciais". Apenas da leitura desse inciso já é possível concluir pela não recomendação de o juiz atuar na conciliação se, na localidade onde atua existirem os profissionais com competência específica para tanto.

Em consonância com este entendimento, o artigo 166 do CPC define os princípios que regem a conciliação e a mediação, trazendo, dentre outros, a independência, a autonomia da vontade e a confidencialidade. Esses princípios marcam a possibilidade de existência de um procedimento de conciliação desvinculado do processo judicial, tramitando paralelamente a este, mas que, a depender do resultado, interferirá totalmente na via judicial. Em verdade, acredita-se que os princípios arrolados no artigo 166 permitem interpretar que o juiz da causa não é, em definitivo, o sujeito recomendado para a função, mas tão somente os profissionais específicos para tal. Vislumbra-se uma razão elementar: caso o juiz da causa conduza a conciliação, cada parte não será livre para expor suas condições apropriadamente, com receio de contaminar o julgador com fatos - intra ou extra autos - que deponham contra si; e, caso exponham as condições abertamente, seguramente o juiz sairá do processo conciliatório com impressões a favor de uma ou outra parte, comprometendo a necessária imparcialidade.

A conciliação, em procedimento próprio e independente, é uma alternativa dada pelo sistema para valorizar as resoluções de conflito informais, mas que atinjam os resultados esperados de acordo com o conjunto de princípios e valores éticos coletivamente partilhados.

É uma visão moderna que permite aliar a formalidade dos sistemas ao dinamismo dos casuísmos, ambos necessários para a construção de soluções. Um traço marcante do novo CPC, como já dito, é dar considerável relevância às escolhas do jurisdicionado, as quais poderão moldar totalmente o procedimento em prol da solução do conflito, conforme artigo $190^{7}$, cujo poder de intervenção do juiz só é cabível em caso de notória situação de vulnerabilidade de uma parte em relação à outra.

Isso está em consonância direta com o que já afirmava Clóvis do Couto e Silva (2006, p.69), sobre a relação entre sistemas e casuísmo na produção de efeitos juridicamente relevantes:

Para superar a forma mentis meramente axiomática, aplicaram uns o conceito hegeliano de "concreto-geral", e outros recorreram aos topoi ou loci (da "Tópica"), ou seja, ao raciocínio casuístico.

O perigo que aí desponta é o término do sistema, ainda que lato sensu, substituído pelo que se denominou pluralidade de sistemas.

A coexistência, porém, do raciocínio dedutivo com o casuístico não é nova na história do pensamento ocidental. Essa concomitância manifesta-se em quase todas as épocas. Nos últimos dois séculos, apenas, ele se fez menos presenta na filosofia e consequentemente em todas as ciências que com ela vivem em mútua relação, como o direito.

Em suma, a sistemática atual é predominantemente dedutiva, mas dá larga margem para que se possa pensar casuisticamente, do que pode resultar a

\footnotetext{
${ }^{6}$ Art. 16. Ainda que haja processo arbitral ou judicial em curso, as partes poderão submeter-se à mediação, hipótese em que requererão ao juiz ou árbitro a suspensão do processo por prazo suficiente para a solução consensual do litígio.

${ }^{7}$ Art. 190. Versando o processo sobre direitos que admitam autocomposição, é lícito às partes plenamente capazes estipular mudanças no procedimento para ajustá-lo às especificidades da causa e convencionar sobre os seus ônus, poderes, faculdades e deveres processuais, antes ou durante o processo.
}

Revista de Direito Brasileira | São Paulo, SP | v. 20 | n. 8 | p. 192-214 |Mai./Ago. 2018 
descoberta de novos princípios e a formação de novos institutos. E assim é porque, embora a codificação possa ter a virtualidade de revogar todas as normas conflitantes com o novo código, não terá a virtude de ab-rogar, entretanto, todos os princípios jurídicos, mormente aqueles considerados fundamentais.

Quanto mais o sistema engessa o sujeito, menos ele terá liberdade para cooperar na busca por soluções dos problemas que o envolve. Isso significa que o maior envolvimento quantitativo de sujeitos na resolução de litígios se dará na medida em que o sistema abre o conceito de sujeitos, e envolver terceiros não diretamente ligados no litígio para sua solução.

Nesse sentido, a título de exemplo, os artigos 772 , III e $773^{8}$ atribuem que terceiros indicados pelo exequente - mas não a ele vinculados em relação material - deterão o dever de cooperar para a eficácia da tutela executiva. Outro exemplo, o $\$ 2^{\circ}$ do artigo 792 atribui ao terceiro adquirente o dever de comprovar que adotou todas as cautelas necessárias antes da aquisição de bem não sujeito a registro, sob pena de perder aquele bem por fraude à execução.

Não se pode esquecer, também, a eficaz descentralização de funções do $\S 1^{\circ}$ do artigo 269, ao permitir que o ente privado - o advogado - exerça a função pública de intimar a outra parte por meio do correio.

Em síntese, a amplitude do conceito de sujeitos do processo pode ser observada do texto do artigo 77 do Código, o qual atribui deveres específicos não só às partes e seus procuradores. Mesmo que a localização topográfica do artigo 77 seja o capítulo destinado aos deveres das partes e procuradores, o termo "todos aqueles que de qualquer forma participem do processo" amplia a abrangência da regra, atingindo a todos os sujeitos do processo, definidos ou indefinidos.

Mesmo que o texto do artigo 77 se aproxime bastante do Código revogado ${ }^{9}$, esse mesmo enunciado normativo agora está inserido em um outro sistema, o qual foi inaugurado pelos noveis artigos $5^{\circ}$ - o qual reitera a indeterminação dos sujeitos, pontuando que qualquer pessoa pode ter participação no processo - e, principalmente, o $6^{\circ}$, que atribui a cooperação como um dever a todos os sujeitos.

Há, portanto, esforço sistemático do Código no sentido de ampliar o conceito de sujeito, bem como a própria abrangência do termo sujeitos do processo, ampliando o compartilhamento do dever estatal de solução de litígio a um rol indeterminado de pessoas.

\section{A COOPERAÇÃO COMO PRINCÍPIO, REGRA E MODELO DE ORGANIZAÇÃO DE UM PROCESSO DEFINIDO PELO CONTRADITÓRIO}

A partir da premissa de que "princípios" são instrumentos que remetem o intérprete da norma "a valores e a diferentes modos de promover resultados", sem, no entanto, "examinar quais são os instrumentos metódicos essenciais à fundamentação controlável da sua aplicação" (ÁVILA, 2004, p. 56), é correto classificar a cooperação exposta no artigo $6^{\circ}$ do CPC como um princípio.

Diversamente ao que expõe Daniel Neves (2015, p.16), a inexistência de qualquer sanção no texto do artigo $6^{\circ}$ não retira, necessariamente, a eficácia normativa da cooperação,

\footnotetext{
${ }^{8}$ Art. 772. O juiz pode, em qualquer momento do processo:

III - determinar que sujeitos indicados pelo exequente forneçam informações em geral relacionadas ao objeto da execução, tais como documentos e dados que tenham em seu poder, assinando-lhes prazo razoável.

Art. 773. O juiz poderá, de ofício ou a requerimento, determinar as medidas necessárias ao cumprimento da ordem de entrega de documentos e dados.

${ }^{9}$ O Art. 14 do CPC/73 assim dizia: "são deveres das partes e de todos aqueles que de qualquer forma participam do processo:".
} 
conforme expôs Didier já em 2010, quando publicou obra analisando o princípio, à época positivado no artigo $266^{\mathrm{o} 10}$ do CPC português:

Entendo que o art. $266^{\circ}$, 1, do CPC português, será mais bem compreendido e aplicado se partirmos das seguintes premissas: a) o dispositivo consagrou um novo modelo de direito processual civil, que redefine o modelo de processo equitativo (due processo of law, devido processo legal, fair trial) português; $b$ ) trata-se de texto normativo do qual se pode extrair uma norma (princípio) que possui eficácia jurídica direta, independentemente de regras que o concretizem; $c$ ) é exemplo de cláusula geral; $d$ ) trata-se também de corolário do princípio da boa fé processual; $e$ ) sua sistematização não pode prescindir de tudo quanto já se construiu dogmaticamente sobre cooperação obrigacional. (DIDIER JR., 2010, p. 12).

Mesmo diante de tal "eficácia jurídica direta", o nosso CPC 2015 trouxe diversos dispositivos esparsos, classificados também como regras - e que serão detalhadas em capítulo próprio, mais adiante - que reiteram esse valor agora positivado. Nesse contexto, nosso sistema jurídico recebeu o valor cooperação como princípio e como regra. E ainda, dentro de sua acepção principiológica, a cooperação também é vista como um modelo de organização do processo.

Tradicionalmente, pelo menos para fins didáticos, a doutrina trata da existência de dois modelos de organização processuais clássicos: o adversarial (ou dispositivo) e o inquisitivo. Enquanto no modelo adversarial o protagonismo é das partes, e o órgão jurisdicional é relativamente passivo - cuja incumbência limita-se a sentenciar - no modelo inquisitivo o órgão jurisdicional é o grande protagonista que organiza o processo como uma pesquisa oficial, no qual as partes atenderão aos seus critérios de busca por soluções (DIDIER JR., 2015a, p. 120-121).

É possível relacionar, num primeiro momento, o modelo adversarial ao common law, e o inquisitivo ao civil law, mas não é correto afirmar que cada cultura jurídica adota um único modelo, ou seja, sempre haverá elementos do modelo adversarial no civil law, por exemplo (DIDIER JR., 2015a, p. 122).

Essa constatação evidencia a estreita correlação existente entre os estudos da sociologia de Roberto Kant de Lima (1999) trazidos anteriormente nesse trabalho e a base teórica jurídica ora adotada. Como visto, mesmo o modelo adversarial predominante nos EUA é alvo de severas críticas, sobretudo por injustiças cometidas contra as partes mais fracas.

Teoricamente, cada modelo de processo corresponde a um extremo, Fredie Didier e Daniel Mitidiero (2007, p. 73) defendem que a cooperação corresponde a uma terceira via, exatamente identificada como mediadora dos modelos clássicos ${ }^{11}$, definindo, agora, "o modo como o processo civil deve estruturar-se no direito brasileiro" a partir do somatório entre o

${ }^{10}$ A redação final do Código português, de junho de 2013 , tratou da cooperação no artigo $7^{\circ}$, com o seguinte texto: 1 - Na condução e intervenção no processo, devem os magistrados, os mandatários judiciais e as próprias partes cooperar entre si, concorrendo para se obter, com brevidade e eficácia, a justa composição do litígio. 2 - O juiz pode, em qualquer altura do processo, ouvir as partes, seus representantes ou mandatários judiciais, convidando-os a fornecer os esclarecimentos sobre a matéria de facto ou de direito que se afigurem pertinentes e dando-se conhecimento à outra parte dos resultados da diligência. 3 - As pessoas referidas no número anterior são obrigadas a comparecer sempre que para isso forem notificadas e a prestar os esclarecimentos que lhes forem pedidos, sem prejuízo do disposto no n. ${ }^{\circ} 3$ do artigo 417. .4 - Sempre que alguma das partes alegue justificadamente dificuldade séria em obter documento ou informação que condicione o eficaz exercício de faculdade ou o cumprimento de ónus ou dever processual, deve o juiz, sempre que possível, providenciar pela remoção do obstáculo. (Portugal. 2013).

${ }^{11}$ Não seria a primeira vez em que o ordenamento brasileiro simbolizaria a adoção de um sistema híbrido. Zaneti Jr. (2005, p.43), ao conceituar "paradoxo metodológico" destacou que nossa tradição é peculiar, híbrida, uma vez que adota elementos do common law norte-americano e do civil law romano-germânico. 
devido processo legal, a boa-fé processual ${ }^{12}$ e o contraditório(DIDIER JR., 2015a, p. 124). E completa:

Esse modelo caracteriza-se pelo redimensionamento do princípio do contraditório, com inclusão do órgão jurisdicional no rol dos sujeitos do diálogo processual, e não mais como um mero espectador do duelo das partes. $\mathrm{O}$ contraditório é valorizado como um instrumento indispensável ao aprimoramento da decisão judicial, e não apenas como uma regra formal que deve ser observada para que a decisão seja válida. (DIDIER JR., 2015a, p. 125).

Há, portanto, íntima relação entre a cooperação e princípios clássicos do direito, razão pela qual é possível encontrar, na doutrina, produções teóricas - publicadas anos antes das discussões acerca de um novo Código - que já defendiam um processo colaborativo.

O próprio Didier Jr., em seus "Fundamentos do princípio da cooperação no direito processual civil português" antecipou a tese acima afirmada - de que a cooperação é um modelo de processo intermediário entre os modelos adversarial e o inquisitivo - afirmando a importância desse tema para o nosso ordenamento, uma vez que o código lusitano é "uma das principais fontes de estudo para o aperfeiçoamento" da legislação brasileira (DIDIER JR., 2010, p. 11 e 42).

A partir da análise dos conceitos dos princípios envolvidos na temática, percebe-se que a teorização sobre a aplicabilidade da cooperação no processo - mesmo antes do novo CPC converge com a pré-existência deste princípio como elemento da boa-fé objetiva, inaugurada em nosso ordenamento pelo Código Civil (CC) de 2002.

Uma das inovações do Código Civil foi definir que os atos de boa-fé não dependem apenas de condutas negativas, ou seja, não se trata apenas de um não agir de má-fé. Em verdade, a boa-fé objetiva trouxe a ideia de que as boas práticas de conduta derivam também de ações ostensivas - como, por exemplo, o dever de esclarecimento - pautadas em padrões éticos que regem os espaços coletivos. Essas ações ostensivas são "o que a doutrina moderna denomina violação positiva da obrigação ou do contrato", de modo que o descumprimento de deveres anexos (como o citado dever de esclarecimento), pode provocar o inadimplemento do contrato mesmo inexistindo a mora do dever principal (GONÇALVES, 2008, p, 38).

A doutrina civilista individualiza esses deveres anexos que compõem a boa-fé objetiva em rol aberto a novos conceitos:

Esses deveres anexos ou secundários excedem o dever de prestação e derivam diretamente do princípio da boa-fé objetiva, tais como os deveres laterais de esclarecimento (informações sobre o uso do bem alienado, capacitações e limites), de proteção (como evitar situações de perigo), de conservação (coisa recebida para experiência), de lealdade (não exigir cumprimento de contrato com insuportável perda de equivalência entre as prestações), de cooperação (prática dos atos necessários à realização plena dos fins visados pela outra parte) etc. (AGUIAR JR. apud GONÇALVES, 2008, p, 39).

A boa-fé objetiva, e consequentemente a cooperação, portanto, no âmbito privado do Direito Civil, especificamente nos contratos, tem por objetivo convergir as partes ao cumprimento do acordo, sem que sejam esquecidos os interesses individuais que buscam as respectivas maximizações de resultados. Não restam dúvidas de que a adaptação da cooperação

\footnotetext{
${ }^{12}$ Sobre a boa-fé relacionada à cooperação: DIDIER Jr. (2010, p.79-103), pelo qual o autor destaca a sistematização da doutrina alemã de quatro casos de aplicação da boa-fé ao processo: “a) proibição de criar dolosamente posições processuais (...); b) a proibição de venire contra factum proprium; c) a proibição de abuso de poderes processuais; d) (...) supressio: perda de poderes processuais em razão do seu não-exercício por tempo suficiente para incutir no outro sujeito a confiança legítima de que esse poder não mais seria exercido."
}

Revista de Direito Brasileira | São Paulo, SP | v. 20 | n. 8 | p. 192-214 |Mai./Ago. 2018 
ao processo não exige de uma parte que auxilie a outra a atingir os seus fins. Mas exige que todos os sujeitos do processo atuem por se obter, em tempo razoável, a decisão de mérito.

A cooperação no processo, então, não dará protagonismo às partes, nem ao juiz; igualmente, ela não exige que as partes passam a agir harmoniosamente contrariamente aos seus próprios interesses, como se não existisse litígio. Ela consistirá em uma divisão de trabalho para o alcance da decisão de mérito envolvendo todos os sujeitos do processo. Nesse sentido, no que tange à condução do processo, os deveres de conduta de todos os sujeitos são paritários, mas no que concerne ao momento da decisão, os deveres de conduta serão assimétricos, uma vez que, de todos os sujeitos, caso não se alcance qualquer forma de autocomposição (conforme visto no capítulo anterior), caberá apenas ao juiz decidir(DIDIER JR., 2010, p. 48).

Mesmo no novo sistema processual a decisão e a sentença ainda são atos próprios do juiz, trata-se de uma manifestação do poder estatal atribuído ao órgão jurisdicional, o qual proferirá decisão de mérito mais justa e efetiva na medida em que acessou, no curso do processo, as informações necessárias para tanto. Essa situação, em absoluto, não significa que o órgão jurisdicional estará totalmente isolado, ou totalmente afastado dos limites apresentados no processo, uma vez que, se a cooperação decorre do devido processo e do contraditório, ela irá moldar a própria decisão. Sobre o tema, Zaneti Jr. (2005, p.266-267) foi claro ao relacionar os princípios constitucionais como elementos de demarcação da atividade jurisdicional:

A Constituição Federal de 1988, ao incluir em seu texto diversos princípios de direito processual que não estavam anteriormente expressos (v.g. devido processo legal) ou que tinham âmbito mais limitado (v.g. contraditório) assumiu expressamente esta postura garantista. É justamente no contraditório, ampliado pela Carta do Estado Democrático brasileiro, que se irá apoiar a noção de processo democrático, o processo como procedimento em contraditório (FAZZALARI), que tem na sua matriz substancial a "máxima da cooperação"(KooperationsMaxima). Trata-se de "extrair do próprio direito fundamental de participação a base constitucional para o princípio da colaboração". O contraditório surge então renovado, não mais unicamente como garantia do direito de resposta, mas sim como: direito de influência e dever de debate.

[negritos e itálicos presentes no original do texto]

A cooperação, agora positivada, destaca a abrangência do contraditório para além das partes, uma vez que se trata de um valor-fonte do processo democrático ${ }^{13}$. Isso significa que, mesmo a atividade jurisdicional, em seu isolamento, será atingida pelo contraditório - e pela cooperação - na medida em que terá de ser devidamente fundamentada a partir do material colhido no curso do processo (MITIDIERO, 2007, p. 100).

Essa ideia foi abarcada pelo novo código em diversos pontos, como, por exemplo, a obrigatoriedade de oitiva prévia da parte antes de qualquer decisão (artigo $9^{\circ}$ ); a necessidade de se oportunizar manifestação à parte antes de qualquer decisão, mesmo que se trate de matéria que se possa conhecer de ofício (artigo 10); ou ainda - e talvez o mais impactante - a prévia definição do que seja ou não uma decisão fundamentada no rol exposto pelo $\S 1^{\circ}$ do artigo 489 .

Ao mesmo tempo em que o novo CPC cria rol para definir o que seja uma decisão fundamentada, o novo texto, ainda, não criou dispositivo correspondente ao antigo artigo $131^{14}$, extinguindo do novo sistema o livre convencimento motivado, pelo qual o julgador não estava vinculado aos argumentos das partes, e não se falava em nulidade, desde que desse alguma motivação para o seu ato decisório.

\footnotetext{
${ }^{13}$ Sobre o contraditório como valor-fonte e como definidor do processo, indicamos Zaneti Jr. (2005, p.103).

${ }^{14}$ Art. 131. O juiz apreciará livremente a prova, atendendo aos fatos e circunstâncias constantes dos autos, ainda que não alegados pelas partes; mas deverá indicar, na sentença, os motivos que Ihe formaram o convencimento.
}

Revista de Direito Brasileira | São Paulo, SP | v. 20 | n. 8 | p. 192-214 |Mai./Ago. 2018 
Há, agora, uma participação integrada dos sujeitos na atividade jurisdicional, cuja base é o próprio princípio democrático, o qual impõe que nenhum processo será "devido" sem o componente da participação, sem a possibilidade de "exercício democrático do poder ou da autonomia da vontade" (BARREIROS, 2011, p. 185).

\section{A EFICÁCIA NORMATIVA DA COOPERAÇÃO}

A positivação da cooperação não afasta o caráter litigioso do processo, mas destaca o traço civilizatório da lealdade em um contexto de conflito. Se não existisse lealdade no litígio, não haveria que se falar em processo, ou em qualquer meio civilizatório de solução de conflitos. A cooperação determina que os sujeitos devam agir por fomentar o diálogo, afastando a ideia de guerra, de modo que o processo seja um ambiente propício para a solução jurídica do conflito.

A partir do texto do Código é possível perceber que a redação legal exige uma nova visão por parte do intérprete, e apenas assim se construirá um novo sistema. É certo concluir, então, que não haverá que se falar em eficácia normativa desse novo modelo de organização processual se o intérprete permanecer preso a antigos padrões formais, e a velhas relações de poder incoerentes com as demandas sociais modernas.

Como asseveram Dierle Nunes e Alexandre Bahia, o Judiciário vem sendo utilizado tanto como instrumento social contramajoritário ${ }^{15}$ (contra as maiorias eventuais manifestadas pelo exercício democrático), como, paradoxalmente, instrumento de manutenção de poder por forças conservadoras que objetivam frear avanços sociais. ${ }^{16}$ Se se trata da mesma lei, regida pela mesma Constituição, os diversos efeitos pragmáticos decorrentes do processo dependerão da forma como o intérprete lê e aplica o texto.

Caso se mantenha a velha visão procedimental formalista liberal sobre o texto do novo Código, certamente não veremos o nascimento de um novo sistema, mas a reprodução do antigo sob novo texto.

Para se evitar essa reprodução, pontuamos alguns exemplos de regras específicas, expressas no novo $\mathrm{CPC}$, as quais, lidas isolada ou sistematicamente, atrairão o adequado raciocínio lógico que dá base à compreensão da cooperação como novo modelo de organização processual.

O ponto de partida dessa sistematização é o artigo $6^{\circ}$, o qual determina que todos os sujeitos do processo devem cooperar entre si em prol da obtenção de decisão de mérito justa e efetiva em tempo razoável. Trata-se de norma geral que afasta a ideia de subordinação entre sujeitos, especialmente a ideia intangível de poder concentrado de um sujeito sobre o outro, atraindo a premissa de divisão de trabalho para um fim específico.

Como a cooperação possui relação estreita com a boa-fé, a norma geral do artigo $6^{\circ}$ deve ser lida em convergência com o artigo $5^{\circ}$, o qual estende o agir probo a todos que "de qualquer forma participa do processo", o que, por sua vez, sedimenta o entendimento de que a ordem do artigo 77 não se limita às partes e seus procuradores, apesar de estar neste capítulo, mas abrange

\footnotetext{
15“Minorias devem poder buscar amparo no Judiciário para se evitar o descumprimento da Constituição frente a maiorias (eventuais). O Parlamento, numa democracia plural, deve espelhar essa pluralidade e estar "sensível" às demandas, de forma que, mesmo que um argumento seja hoje vencedor, isso não o impeça o órgão de "resgatar" os demais antes vencidos." (NUNES \& BAHIA, 2010, p. 62).

16،"Importa termos presente um ponto geralmente desconsiderado: é que o uso do Judiciário pode ser uma faca de dois gumes, pode se dar tanto na busca por avanços no que toca aos Direitos Fundamentais, mas também pode ser utilizado por setores conservadores interessados justamente em barrar avanços democráticos - algo que Boaventura de Sousa Santos em texto recente chama de contrarrevolução jurídica, lembrando ações como as que visaram anular políticas de cotas para negros em universidades; ações contra demarcação de terras indígenas e quilombolas; criminalização do MST, etc." (NUNES \& BAHIA, 2010, p. 69).
}

Revista de Direito Brasileira | São Paulo, SP | v. 20 | n. 8 | p. 192-214 |Mai./Ago. 2018 
igualmente todos os sujeitos do processo. Além dessa leitura sistemática, o próprio texto do artigo 77 assim se apresenta: "além de outros previstos neste Código, são deveres das partes, de seus procuradores e de todos aqueles que de qualquer forma participem do processo".

A discussão toma relevo na medida em que, com exceção das partes e procuradores, a lei prevê que a sanção geral aos demais sujeitos do processo elencados no Livro III da Parte Geral do Código é a de responsabilização civil e regressiva ${ }^{17}$, o que, por consequência, depende do ajuizamento de ação específica pela parte que se julgar prejudicada.

No entanto, o $\$ 2^{\circ}$ do artigo 77 estabelece que, nas hipóteses dos incisos IV e VI ${ }^{18}$, além das sanções cíveis, criminais e processuais cabíveis, o sujeito que cometer aquelas infrações praticará ato atentatório à dignidade da justiça, punível com multa de até vinte por cento do valor da causa, de acordo com a gravidade da conduta. Essa multa não é devida a qualquer parte, mas aos cofres públicos, nos termos do $\$ 3^{\circ}$ do artigo 77 .

Adequada leitura do $\S 2^{\circ}$ do artigo 77 atrairá a responsabilidade pessoal, punível mediante multa, nos próprios autos, a todos os sujeitos - parciais e imparciais - que violarem os importantes deveres de lealdade e cooperação expressos nos incisos IV e VI do caput.

Exatamente por força dessa leitura sistemática, aliando os artigos $5^{\circ}, 6^{\circ}$ e 77 do $\mathrm{CPC}$, é dogmaticamente ilógica a exceção prevista no $\$ 6^{\circ}$ do artigo 77 , que expressamente isenta os advogados públicos e privados, e os membros da Defensoria Pública e do Ministério Público da aplicação da sanção prevista no citado $\S 2^{\circ}$. Tais exceções expressam uma ampliação do rol de sujeitos abarcados pela isenção que no CPC/73 era conferida apenas ao advogado pelo parágrafo único $^{19}$ do artigo 14 do Código revogado.

Tais exceções são contraditórias à abrangência geral da cooperação enquanto corolário de boa-fé e lealdade, e no novo Código essas exceções não são contrárias apenas ao texto do caput do artigo 77, mas também às normais fundamentais do Processo Civil previstas nos artigos $5^{\circ}$ e $6^{\circ}$ do novo texto.

No entanto, sabe-se que os órgãos de classe - especialmente os órgãos daquelas classes mencionadas na exceção do $\$ 6^{\circ}$ - exercem forte influência nos processos legislativos, interferindo diretamente na vontade do legislador, o qual, influenciado pelas diversas pressões políticas, aprova texto nutrido de contradições, ou ainda preso aos velhos costumes.

Por isso o destaque dado pela doutrina à necessidade de uma adequada leitura da lei, na construção da norma $^{20}$, que envolva todos os sujeitos do processo aos deveres e às sanções previstas, tal como expresso no artigo $6^{\circ}$. E tal leitura não deve vedar os olhos às pessoas que representam o Estado no processo, nem aos sujeitos imparciais, os quais não podem manter a sintonia belicosa instaurada pelas partes (NEVES, 2015, p. 16).

Nesse contexto, considerando que a cooperação abarca todos os sujeitos do processo, a doutrina sistematizou deveres, baseados nas diversas regras legais, os quais são definidos de

\footnotetext{
${ }^{17} \mathrm{O}$ CPC faz as previsões de responsabilidade civil regressiva ao juiz (artigo 143), escrivão, chefe de secretaria , oficial de justiça (artigo 155), perito (artigo 158, o qual amplia a sanção à inabilitação para atuar em outras perícias por determinado prazo), depositário e administrador (artigo 161), membro do Ministério Público (artigo 181), membro da Advocacia Pública (artigo 184) e o Defensor Público (artigo 187).

${ }^{18} \mathrm{IV}$ - cumprir com exatidão as decisões jurisdicionais, de natureza provisória ou final, e não criar embaraços à sua efetivação;

VI - não praticar inovação ilegal no estado de fato de bem ou direito litigioso.

${ }^{19}$ Parágrafo único. Ressalvados os advogados que se sujeitam exclusivamente aos estatutos da OAB, a violação do disposto no inciso $\mathrm{V}$ deste artigo constitui ato atentatório ao exercício da jurisdição, podendo o juiz, sem prejuízo das sanções criminais, civis e processuais cabíveis, aplicar ao responsável multa em montante a ser fixado de acordo com a gravidade da conduta e não superior a vinte por cento do valor da causa; não sendo paga no prazo estabelecido, contado do trânsito em julgado da decisão final da causa, a multa será inscrita sempre como dívida ativa da União ou do Estado.

${ }^{20}$ Como defendido no presente trabalho, o artigo $6^{\circ}$ possui eficácia direta, tal como referenciado em Didier Jr..(2010, p.12). Contudo, é sabido que a divergência de interpretações define a aplicação da norma, razão pela qual compreendemos o risco do artigo se tornar letra morta caso não existissem as regras esparsas pelo CPC.
} 
forma diversa entre os sujeitos parciais (partes, advogados, defensores, Ministério Público quando atua como parte, por exemplo) e os sujeitos imparciais (juiz, peritos, o Ministério Público quando atua como fiscal da ordem jurídica etc.).

No que tange aos sujeitos imparciais, têm-se os deveres de esclarecimento, consulta e prevenção.

\subsection{Os deveres dos sujeitos imparciais: Esclarecimento}

O esclarecimento atrai a necessidade de os atos decisórios serem mais detalhados, com fundamentação especificada à hipótese dos autos (DIDIER JR., 2015a, p. 128). É o caso, como já tratado, da necessidade de adequação aos preceitos do $\S 1^{\circ}$ do artigo 489 , sob pena de não se considerar fundamentada - portanto nula - a decisão. Não se admitem mais meras referências a súmulas, por exemplo, sem o cotejo analítico entre os paradigmas e o caso sob julgamento (artigo $\left.489, \S 1^{\circ}, \mathrm{V}^{21}\right)$.

Deve haver uma clara vinculação entre a decisão/sentença e os fundamentos determinantes trazidos pelas partes no curso do processo, o que obriga o julgador a enfrentar esses motivos determinantes, assim classificados os argumentos que, em tese, têm o potencial de alterar o resultado final do julgamento. Esse é o sentido do inciso $I V^{22}$ do $\$ 1^{\circ}$ do artigo 489, cujo desrespeito atrai à parte prejudicada o direito de interpor Embargos de Declaração nos termos do artigo 1.022, parágrafo único, $\mathrm{II}^{23}$.

Essa vinculação da sentença aos argumentos determinantes expõe importante limitação ao poder de decidir do Estado Juiz, o qual, agora, deve refletir o debate claro firmado pelos diversos sujeitos no curso do processo, afastando-se a ideia de um poder exercido com base em um livre convencimento que ignorava a dialética processual.

\subsection{Os deveres dos sujeitos imparciais: Consulta}

Outro dever é o de consulta, que decorre do contraditório, e se manifesta, por exemplo, com a obrigatoriedade de o juiz intimar as partes antes de proferir qualquer decisão, "ainda que se trate de matéria sobre a qual deva decidir de ofício", conforme artigo 10(DIDIER JR., 2015a, p. 129).

Também faz parte do dever de consulta, do juiz, o saneamento compartilhado expresso no $\$ 3^{\circ}$ do artigo 357 , pelo qual "se a causa apresentar complexidade em matéria de fato ou de direito, deverá o juiz designar audiência para que o saneamento seja feito em cooperação com as partes, oportunidade em que o juiz, se for o caso, convidará as partes a integrar ou esclarecer suas alegações".

Um terceiro exemplo do dever de consulta está no artigo 365, e pode servir de ponto de partida para uma importante problematização acerca do exercício e dos limites do dever de consulta. O referido artigo expõe que: "A audiência é una e contínua, podendo ser excepcional e justificadamente cindida na ausência de perito ou de testemunha, desde que haja concordância das partes".

O texto legal determina que a audiência de instrução e julgamento deve se realizar em ato uno e contínuo, de modo que sua cisão deve ser excepcional, e só é permitida se reunidos dois

\footnotetext{
${ }^{21} \S 1^{\underline{0}}$ Não se considera fundamentada qualquer decisão judicial, seja ela interlocutória, sentença ou acórdão, que: V - se limitar a invocar precedente ou enunciado de súmula, sem identificar seus fundamentos determinantes nem demonstrar que o caso sob julgamento se ajusta àqueles fundamentos;

${ }^{22}$ IV - não enfrentar todos os argumentos deduzidos no processo capazes de, em tese, infirmar a conclusão adotada pelo julgador;

${ }^{23}$ Art. 1.022. Cabem embargos de declaração contra qualquer decisão judicial para: (...) II - suprir omissão de ponto ou questão sobre o qual devia se pronunciar o juiz de ofício ou a requerimento; (...) Parágrafo único. Considera-se omissa a decisão que: (...) II - incorra em qualquer das condutas descritas no art. $489, \S 1^{\circ}$.
} 
elementos: a devida justificativa (ausência de perito ou de testemunha) e a concordância das partes.

O dever de consulta é claro nesse dispositivo, uma vez que o juiz apenas poderá cindir a audiência caso, depois de ouvidas as partes, elas concordarem. No entanto, é correto afirmar que esse direito de dar anuência, inerente às partes, não é absoluto e imotivado, uma vez que também necessitará do devido fundamento, como expressão do adequado exercício da dialética. A devida justificativa pela falta de anuência é condição sine qua non para a aceitação dessa recusa.

Além disso, não há necessidade de concordância de ambas as partes; a anuência de uma delas é motivo suficiente para dar base legal ao juiz para a cisão do ato. Caso o entendimento não seja esse, se admitirá um direito potestativo pelo qual uma parte submeteria as demais partes e o juiz à sua vontade, já que o seu veto isolado obrigaria a realização da audiência na íntegra sem a presenta de perito ou de alguma testemunha, o que afrontaria outros princípios elementares do processo, como o contraditório e a ampla defesa.

Deve ficar claro, portanto, que a cisão do ato poderá ocorrer com a anuência de pelo menos uma das partes, não de todas.

Fica claro, portanto, que o dever de consulta, assim como toda cooperação, não é ilimitada, mas, assim como todos os princípios presentes no ordenamento, deve respeitar os limites dos demais princípios.

\subsection{Os deveres dos sujeitos imparciais: Prevenção}

Pelo dever de prevenção, por fim, o sujeito deve agir por conduzir o processo à decisão de mérito, evitando-se a contaminação por vícios formais, ou promovendo-se o saneamento dos eventuais vícios observados. Através da prevenção, por exemplo, o juiz deve apontar as falhas processuais e, com isso, preservar o processo enquanto elemento de solução do litígio, evitando o julgamento sem análise de mérito. A prevenção "vale genericamente para todas as situações em que o êxito da ação ou da defesa possa ser frustrado pelo uso inadequado do processo" (DIDIER JR., 2015a, p. 130).

São exemplos da prevenção, os artigos 317 (Antes de proferir decisão sem resolução de mérito, o juiz deverá conceder à parte oportunidade para, se possível, corrigir o vício) e a parte final do artigo 321 (a determinação judicial de complementação ou emenda à inicial será acompanhada da indicação precisa do que deve ser corrigido ou completado).

A mesma lógica é aplicada no âmbito dos recursos, vigendo a regra geral da possibilidade de saneamento de vícios e a complementação de documento obrigatório não juntado em tempo, nos termos do parágrafo único do artigo 932. Essa regra é reiterada nos casos de vícios observados no pagamento das custas recursais, nos termos dos $\S \S 2^{\circ}, 4^{\circ}$ e $7^{\circ}$ do artigo 1.007. Em ambos os casos, o mérito recursal apenas não será decidido se a parte, intimada, não cumprir com o dever de sanar o vício no prazo legal.

Em sede recursal é notória a inclinação do novo texto em reduzir as hipóteses de jurisprudência defensiva, voltada historicamente à redução do acesso às vias recursais com base em filigranas formais, em detrimento da análise de mérito.

A prevenção requer maior atenção e conhecimento técnico pelos sujeitos do processo, especialmente do juiz, o qual não possui mais o poder de extinguir o feito sem resolução de mérito se não apontar, especificamente, os vícios processuais eventualmente encontrados. Com isso fica superada a valorização do procedimento em detrimento da resolução de mérito, tornando o processo mais acessível, menos centralizado em uma autoridade.

$\mathrm{O}$ antigo formalismo exacerbado limitava o acesso ao judiciário, pois exigia excessiva atenção à forma, além da complexidade natural do litígio, de modo que, muitas vezes, a forma era priorizada em detrimento da solução do conflito, a exemplo da própria jurisprudência defensiva, manifestada nas várias súmulas que tratam de questões procedimentais. 


\subsection{Os deveres dos sujeitos parciais}

Como tratado no decorrer do presente texto, a cooperação abrange todos os sujeitos do processo, parciais e imparciais, trazendo um conjunto de regras que corroboram o princípio inaugurado pelo artigo $6^{\circ}$. Além disso, foi dito que é função dos sujeitos imparciais não se deixarem influenciar pela sintonia belicosa instaurada pelas partes; se dois ou mais litigantes elegem o Judiciário para solucionar seus conflitos, é porque o sistema jurídico, e os sujeitos que o compõem, devem analisar as questões litigiosas com espírito pacífico.

Como os sujeitos parciais requerem atenção diversificada em relação aos imparciais, é adequado, também, enxergar a cooperação de forma diversa para cada tipo de sujeito. Quando o espírito litigioso se faz presente, no caso dos sujeitos parciais, a cooperação é limitada pelos princípios do contraditório e da ampla defesa, não havendo que se exigir da parte que abra mão dos meios de defesa legalmente admitidos em prol da cooperação.

Por força dessa diferença no tratamento da cooperação para cada tipo se sujeito, a doutrina define os três deveres do princípio cooperativo de forma diversa (DIDIER JR., 2015a, p. 128-129). Enquanto para os sujeitos imparciais falam-se dos deveres de esclarecimento, consulta e prevenção, para os sujeitos parciais falam-se dos deveres de esclarecimento, lealdade e proteção.

Em alguns casos, cada classificação vale-se da mesma regra, alterando-se o referencial subjetivo. O supracitado $\S 3^{\circ}$ do artigo 357 , por exemplo - pelo qual as partes são convidadas ao saneamento compartilhado - é expressão do dever de consulta inerente ao juiz, de modo que as partes, por sua vez, deverão atender ao chamado em prol de seu dever de esclarecimento.

O objetivo previsto no artigo $6^{\circ}$, reiterado em diversas outras partes do código, é a resolução de mérito justa e efetiva, a qual estará ausente caso as partes não exponham seus argumentos de forma organizada e sistematizada, ou, ainda, se a causa exigir conhecimento técnico avançado, cuja complexidade para a produção de provas exige um consenso quanto ao mérito de instrução processual.

Como dito, produzir uma decisão que enfrente todos os fundamentos determinantes é dever - de esclarecimento - do juiz nos termos do artigo $489, \S 1^{\circ}$; mas a expedição de tal decisão dependerá também do exercício adequado, pelas partes e advogados, do seu dever de esclarecimento, ou seja, de produzirem textos minimante organizadas, expondo esses fundamentos determinantes de forma mais clara e sistemática possível.

Se o novo Código deu amplo valor ao diálogo, à valorização do texto das partes e dos fundamentos lançados, é dever dos sujeitos parciais sistematizarem suas redações e, assim, possibilitarem a otimização do trabalho judicial de atenção ao que dispõe o $\S 1^{\circ}$ do artigo 489 . Em síntese, a adequada manifestação do contraditório implicará, por via de consequência, no exercício da cooperação, já que, como visto, uma sentença de mérito justa e efetiva decorre do contraditório.

Além do contraditório, a cooperação também decorre da boa-fé, conforme também já tratado nesse texto. E a cooperação enquanto manifestação de boa-fé processual fundamenta o segundo dever inerente aos sujeitos parciais: o dever de lealdade.

Reiteramos que a lealdade não se confunde com o esmorecimento da combatividade e da ampla defesa, mas impõe limites as partes, como se vê das regras de conduta processual voltadas a não distorção de fatos, manifestadas nos incisos I e II do artigo 77, bem como incisos I e II do artigo 80 do CPC, por exemplo.

Deve-se esclarecer que o alcance da "verdade" não é tarefa simples, talvez até não seja possível, uma vez que: o processo refletirá um conjunto de versões e provas sobre um fato passado, portanto inacessível em sua integralidade, mas sim apenas presumível; e ainda, mesmo fatos tidos como incontroversos podem gerar uma gama de interpretações diversas que 
classificarão o contexto como justo sob óticas conflitantes. Daí o conceito de alcance da verdade, expressos nos artigos 77 e 80, exigirem um raciocínio mais complexo.

No entanto, por mais que se admita a possibilidade de diversas versões sobre um mesmo fato passado, ou mesmo a existência de diversas verdades sobre fatos incontroversos, há um limite de razoabilidade, fora do qual está a ação desleal condenável pelos artigos 77 e 80 do Código.

Como toda norma parte de interpretações, caberá ao julgador avaliar, caso a caso, a partir de quando há violação ao dever de lealdade, aplicando a sanção cabível.

Por fim fala-se no dever de proteção, cuja origem também pode decorrer da boa-fé, mas sua adequada aplicação se dá pela manutenção da integridade do processo enquanto último meio de solução de conflitos.

Genericamente, o dever de proteção se manifesta pelo respeito aos deveres processuais, bem como pelo respeito às ordens judiciais proferidas de acordo com a legalidade. Seu exercício se dá, por exemplo, com a atenção aos deveres expressos no artigo 77, IV e VI, cujas infrações são classificadas como atos atentatórios à dignidade da justiça.

Também são expressões do dever de proteção a adequada utilização dos mecanismos processuais, sobretudo os recursos, de modo a não transformar o processo em ambiente confuso e desfocado dos parâmetros traçados nas principais manifestações das partes. Daí decorre as vedações aos atos de produção desnecessária de provas - artigo 77, III - bem como de criação de incidentes e recursos manifestamente infundados - artigo 80, VI e VII - por exemplo.

Assim como logo acima, concernente ao dever de lealdade, a percepção de um ato atentatório ao dever de proteção dependerá de análise detalhada e específica pelo julgador, o qual, assim como todo jurista, terá de exercer a adequada interpretação para aplicação da cooperação enquanto norma jurídica.

\section{CONCLUSÕES}

O Direito depende simbioticamente de análises interpretativas para se manifestar de forma concreta no mundo dos fatos. Mesmo a análise puramente dogmática do texto legal, completamente dissociada dos movimentos sociais, requer complexo exercício de leitura e compreensão, e por isso sofre interferência das compreensões e conceitos prévios inerentes a cada intérprete.

Daí nossa reiterada afirmação no seguinte sentido: a cooperação, assim como qualquer novo conceito introduzido pelo CPC 2015, será aplicada na medida da vontade e da compreensão do intérprete.

Primeiramente falamos em "vontade" uma vez que o estudo dos novos conceitos depende de esforço e disciplina, nem sempre presentes nos operadores que preferem se manter nos velhos preceitos do Código revogado. Também falamos em "compreensão", uma vez que o intérprete aplicará os conceitos de forma inovadora se, após sua análise do texto, assim entender; e tal assimilação perpassa pela bagagem teórica do intérprete, bem como sua disposição de se desfazer de velhos preconceitos.

Nesse contexto, procuramos, nesse texto, contribuir com uma nova visão do Processo Civil, baseado no pensamento multidisciplinar moderno e pós-metafísico para fixar a ideia de que a cooperação é um marco civilizatório de nossa sociedade, refletido no texto do novo Código, e não é incompatível com a ideia de conflito.

Como afirmado por Habermas, citado no decorrer do texto, os conflitos são parte da interação humana, e decorrem dos diferentes valores inerentes a cada pessoa. No entanto, esses conflitos não constituem o motor que motiva nossa caminhada; ao contrário, são distorções que podem ser resolvidas por aquilo que nos torna humanos: o diálogo. 
A cooperação, nesse sentido, não busca obrigar as partes a caminharem de mãos dadas em um contexto de litígio, ou seja, ela não deve ser vista afastada de critérios que regulam sua adequada aplicação. Por tais critérios, como visto, a cooperação passa a ter limites específicos, voltados a definição de regras de conduta destinados a todos os sujeitos do processo, que devem encarar o ambiente processual como um local de solução.

Isso atrai uma diferença conceitual importante acerca do objetivo do processo: ele pode ser visto sob o enfoque civilizatório, ou seja, como uma alternativa ao diálogo, de modo que o Estado, e os sujeitos imparciais serão verdadeiros mediadores e pacificadores; ou ele pode ser visto como um substituto da violência humana, pelo qual o Estado supre a consciência e a falta de comunicação. Pelo que desenvolvemos nesse trabalho, enxergar adequadamente a cooperação significa ver o processo predominantemente sob a ótica da primeira alternativa.

\section{REFERÊNCIAS}

ÁVILA, Humberto. Teoria dos Princípios: da definição à aplicação dos princípios jurídicos. 3. ed.. São Paulo: Malheiros, 2004.

BARREIROS, Lorena Miranda Santos. Fundamentos constitucionais do modelo processual cooperativo no direito brasileiro. 2011. 237 p. Dissertação de Mestrado em Direito Público Universidade Federal da Bahia (UFBA), Salvador - BA, 2011. Disponível em <https://repositorio.ufba.br/ri/bitstream/ri/10725/1/ Lorena.pdf>. Acesso em 15 abr. 2016.

BONAVIDES, Paulo; ANDRADE, Paes de. História Constitucional do Brasil. $3^{\text {a }}$ ed. Rio de Janeiro: Ed. Paz e Terra Política, 1991.

BRASIL, Código de Processo Civil: Lei no 13.105 de 16 de março de 2015. Disponível em <http://www.planalto.gov.br/ccivil_03/_ato2015-2018/2015/lei/113105.htm>. Acesso em 21 abr. 2016.

BRASIL, Constituição da República Federativa do Brasil de 1988. Disponível em <http://www.planalto.gov.br/ccivil_03/constituicao/ConstituicaoCompilado.htm>, acesso em 20.jan.2016.

CÂMARA, Alexandre Freitas. Lições de direito processual civil. Vol. 1. 14.ed. Rio de Janeiro: Lumen Juris, 2006.

CINTRA, Antônio Carlos de Araújo; GRINOVER, Ada Pellegrini; DINAMARCO, Cândido Rangel. Teoria geral do processo. 5. ed. São Paulo: Revista dos Tribunais, 1985.

CRISSIUMA, Ricado. Trocando o velho pelo novo: Honneth leitor de Hegel. In: MELO, Rurion. (Coord.) A teoria crítica de Axel Honneth: reconhecimento, liberdade e justiça. São Paulo. Saraiva, 2013. Versão do aplicativo LEV Saraiva.

DIDIER JR., Fredie. Fundamentos do princípio da cooperação no direito processual civil português. Coimbra: Coimbra Editora, 2010.

DIDIER JR., Fredie. Curso de direito processual civil: introdução ao direito processual civil, parte geral e processo de conhecimento. V.1. 17. ed. Salvador: Jus Podivm, 2015a. 
DIDIER JR., Fredie. Parte Geral: das normas processuais civis, artigos $1^{\circ}$ ao 13 . In. CABRAL, Antônio do Passo; CRAMER, Ronaldo (Coords). Comentários ao novo código de processo civil. Rio de Janeiro: Forense, 2015b. Cap.1, p.1-42

DINAMARCO, Cândido Rangel. Instituições de direito processual civil. 3. Ed. São Paulo: Malheiros, 2003, v.2.

GONÇALVES, Carlos Roberto. Direito civil brasileiro: contratos e atos unilaterais. 3.v. 5. ed. São Paulo: Saraiva, 2008.

GUTIERREZ, Gustavo Luis; ALMEIDA, Marco Antônio Bettine de. Teoria da ação comunicativa (Habermas): estrutura, fundamentos e implicações do modelo. Porto Alegre: Revista Veritas. v. 58. n. 1. jan-abr. 2013. p. 151-173.

HABERMAS, Jürgen. Teoria de la acción comunicativa: Trad. Manuel Jiménez Redondo. v.II. Madrid: Taurus, 1887.

HONNETH, Axel. Luta por reconhecimento: a gramática moral dos conflitos sociais. 2.ed. São Paulo: Editora 34, 2009.

HONNETH, Axel. O direito da liberdade. São Paulo: Martins Fontes, 2015.

LIMA, Roberto Kant de. Polícia, justiça e sociedade no Brasil: uma abordagem comparativa dos modelos de administração de conflitos no espaço público. Revista de sociologia e política. Curitiba, n.13, nov. 1999. Disponível em <http://www.scielo.br/pdf/rsocp/n13/a03n13.pdf>. Acesso em 21 abr. 2016.

MAZZEI, Rodrigo. O código civil de 2002 e a sua interação com os microssistemas e a Constituição Federal. Revista da Faculdade Autônoma de Direito. V. 1. P. 245-278, 2011.

MAZZEI, Rodrigo. Breve história (ou 'estória') do direito processual civil brasileiro: das Ordenações até a derrocada do Código de Processo civil de 1973. Revista do Instituto de Hermenêutica Jurídica, v. 16, p. 177-203, 2014.

MITIDIERO. Daniel. Bases para construção de um processo civil cooperativo: o direito processual civil no marco teórico do formalismo-valorativo. 2007. 147 p. Tese de doutorado Universidade Federal do Rio Grande do Sul (UFRS), Porto Alegre - RS, 2007. Disponível em <https://www.lume.ufrgs.br/bitstream/handle/10183/ 13221/000642773.pdf?sequence=1 > . Acesso em 15 abr. 2016.

NEVES, Daniel Amorim Assumpção. Novo CPC: Código de Processo Civil. Inovações, alterações, supressões comentadas. 2.ed. São Paulo: Editora Método, 2015.

NUNES, Dierle; BAHIA, Alexandre. Processo, jurisdição e processualismo constitucional democrático na américa latina: alguns apontamentos. Revista Brasileira de Estudos Políticos. n. 101. P. 61-96, jul./dez. 2010. p.89.

PORTUGAL, Código de processo civil. Lei no 41 de 26 de junho de 2013. Disponível em <http://www.pgdlisboa.pt/leis/lei_mostra_articulado.php?nid=1959\&tabela=leis >. Acesso em 21 abr. 2016. 
RIBEIRO, Renato Janine. Hobbes: o medo e a esperança. In. WEFFORT, Francisco Corrêa (Org.). Os clássicos da política.13.ed. v.01. São Paulo: Ática, 2000. P. 51-79.

SARLET, Ingo Wolfgang. A Eficácia dos Direitos Fundamentais. 2.ed. Porto Alegre: Editora Livraria do Advogado, 2001.

SILVA, Clóvis V. do Couto e. A obrigação como processo. Rio de Janeiro: FGV Editora, 2006.

STRECK, Lênio Luiz et al. A cooperação processual do novo CPC é incompatível com a Constituição. Consultor Jurídico. 2014. Disponível em <http://www.conjur.com.br/2014-dez23/cooperacao-processual-cpc-incompativel-constituicao〉. Acesso em 20. Abr. 2016.

ZANETI Jr.. Hermes. A constitucionalização do processo: a virada do paradigma racional e político no processo civil brasileiro do estado democrático constitucional. 2005. 407 p. Tese de Doutorado em Direito. Universidade Federal do Rio Grande do Sul, Porto Alegre - RS. 2005. Disponível em <http://www.lume.ufrgs.br/ bitstream/handle/10183/4525/000502097.pdf?...1>. Acesso em 21 abr 2016.

ZIZEK, Slavoj. Menos que nada: Hegel e a sombra do materialismo dialético. São Paulo: Boitempo, 2013. 